\section{Delays in access to care for abortion-related complications: the experience of women in Northeast Brazil}

\author{
Atrasos no acesso ao tratamento das complicações \\ relacionadas ao aborto: a experiência das \\ mulheres no Nordeste brasileiro
}

\author{
Retrasos en el acceso a cuidados médicos para \\ complicaciones relacionadas con el aborto: la \\ experiencia de mujeres en el nordeste brasileño
}

Thália Velho Barreto de Araújo 1

Estela M. L. Aquino 2

Greice M. S. Menezes 2

Maria Teresa Seabra Soares de Britto e Alves 3

Maria-da-Conceição C. Almeida 4

Sandra Valongueiro Alves 1

Liberata Coimbra 3

Oona M. R. Campbell 5

doi: $10.1590 / 0102-311 \times 00168116$

\begin{abstract}
Around 18 million unsafe abortions occur in low and middle-income countries and are associated with numerous adverse consequences to women's health. The time taken by women with complications to reach facilities where they can receive appropriate post-abortion care can influence the risk of death and the extent of further complications. All women aged $18+$ admitted for abortion complications to public-sector hospitals in three capital cities in the Northeastern Brazil between August-December 2010 were interviewed; medical records were extracted $(N=2,804)$. Nearly all women (94\%) went straight to a health facility, mainly to a hospital (76.6\%); the rest had various careseeking paths, with a quarter visiting 3+ hospitals. Women waited 10 hours on average before deciding to seek care. 29\% reported difficulties in starting to seek care, including facing challenges in organizing childcare, a companion or transport (17\%) and fear/stigma (11\%); a few did not initially recognize they needed care (0.4\%). The median time taken to arrive at the ultimate facility was 36 hours. Over a quarter of women reported experiencing difficulties being admitted to a hospital, including long waits (15\%), only being attended after pregnant women (8.9\%) and waiting for a bed (7.4\%). Almost all women (90\%) arrived in good condition, but those with longer delays were more likely to have (mild or severe) complications. In Brazil, where access to induced abortion is restricted, women face numerous difficulties receiving post-abortion care, which contribute to delay and influence the severity of post-abortion complications.
\end{abstract}

Abortion; Health Services Accessibility; Medical Care

\author{
Correspondence \\ T. V. B. Araújo \\ Programa de Pós-graduação em Ciências da Saúde, \\ Universidade Federal de Pernambuco. \\ Av. Prof Moraes Rego s/n, Bloco “E”, 4o andar, Cidade \\ Universitária, Recife, PE 50670-901, Brasil. \\ thalia@ufpe.br \\ 1 Universidade Federal de Pernambuco, Recife, Brasil. \\ 2 Instituto de Saúde Coletiva, Universidade Federal da Bahia, \\ Salvador, Brasil. \\ 3 Universidade Federal do Maranhão, São Luís, Brasil. \\ 4 Instituto Gonçalo Moniz, Fundação Oswaldo Cruz, Salvador, \\ Brasil. \\ 5 Faculty of Epidemiology and Population Health, London \\ School of Hygiene and Tropical Medicine, London, U.K.
}




\section{Introduction}

As the illegality of abortion results in unsafe procedures that pose a risk to women's health, abortion complications are common and important contributors to the global disease burden 1,2,3. Abortion is a common event in Brazil, even though it is allowed only in cases of rape, when a woman's life is threatened or, more recently, for fetal anencephaly. The time taken by women with complications to reach facilities where they can receive appropriate post-abortion care can influence the risk of death and the extent of further complications or morbidity sequalae 4 . Delays in care-seeking for complications and accessing health care in pregnancy, delivery and postpartum have long been conceptualized as important contributors to maternal mortality and morbidity 5. Specifically, the three-delays framework of Thaddeus \& Maine 6 identified: (1) delays in recognizing symptoms and seeking care; (2) delays in arriving at an appropriate facility; and finally (3) delays in receiving appropriate treatment within a facility. While abortion complications fall within this framework, there are reasons to consider them separately, because the extent of delays may be exacerbated where abortion is illegal, severely restricted or highly stigmatized. Women may fear social or even legal consequences if other come to know, and healthcare providers may be afraid to treat women with complications 7 . Women may also hesitate for fear of experiencing disrespect or abuse from providers who suspect that an abortion is induced 8,9 .

In this paper, we use the three-delays framework to look at care-seeking behavior for abortion complications in the Northeast of Brazil. In 2013, induced abortions in the country were estimated between 687,347 and 865,160 , with the Northeast having the highest ratio of induced abortions among women between 15 and 49 years, calculated by 100 live births, among the regions of the country 10 . The most-recent national Brazilian abortion survey revealing that $13 \%$ of women had induced at least one abortion, and that about a half of these women had attended a health facility post-abortion and had been hospitalized 11. Hospitalizations for abortion complications, especially severe cases, have been declining in the last decades in Brazil 12, a trend thought to stem from the widespread of misoprostol 13, which, with correct dosage taken, results in complete abortion in $75-90 \% 14$ of times, with low complication levels 9. In 2013, 205,075 women were admitted to public hospitals for abortion-related complications 10 , and abortion has been estimated as the fourth cause of maternal mortality 15 . Brazil has compulsory maternal-death notification, including for abortions, and deaths are investigated, but this is not done in all municipalities 16 .

Hospitals are the appropriate level of facility in which to seek post-abortion care in Brazil, and Brazilian Ministry of Health guidelines 17 explicitly require that post-abortion complications are managed in a humane and technically effective way, so providers managing complications are unlikely to fear legal sanctions.

Nevertheless, the restricted nature of induced abortion in Brazil and the associated stigma may well influence where and how quickly women seek and obtain care, adding a complexity layer to delays that may not apply to different pregnancy complications, such as eclampsia.

\section{Objectives}

The aim of this paper is to: (1) identify the main pathways for women seeking post-abortion care in three Brazilian cities; (2) examine delays and difficulties experienced in care-seeking; and (3) look at the association between delay and condition on arrival.

\section{Methods}

\section{Study design and population}

A multi-centered cross-sectional study (GravSus-NE) was carried out in the capital cities of three states in Northeastern Brazil (Salvador, in Bahia State; Recife, in Pernambuco State; and São Luís, in Maranhão State), between August 31st and December 30th, 2010. These cities have 22 public hospitals 
that provide obstetric and post-abortion care. Hospitals with over 120 hospitalizations in the previous year were included (19 hospitals). Brazilian law and ethics approval procedures require parents/ guardians to sign consent forms for research participants aged below eighteen. We deemed it inappropriate to seek such consent for young women, and so excluded minors, and all resident women, aged 18 or over, admitted for abortion complications in the 19 eligible hospitals, were invited to participate in the study, irrespective of whether their abortion (defined as pregnancy ending up to 22 weeks of gestation) was induced or spontaneous. Women admitted for a legal induced-abortion procedure, or whose abortion stemmed from an ectopic pregnancy, hydatidiform mole or another abnormal product of conception (International Classification of Diseases, 10th revision - ICD-10), were ineligible. Eligible women who consented were interviewed by trained female health-professionals using standardized questionnaires, and additional information was obtained from medical records. Data were anonymized and confidentiality assured.

To classify the women's clinical condition on admission to the ultimate hospital, we convened an expert committee to reach a consensus for defining the degree of complications in the context of Brazil, with the consensus used shown in Box 1.

Data were analyzed using parametric and non-parametric methods, as appropriate, with both IBM SPSS (IBM Corp., Armonk, USA) and Stata software (StataCorp LP, College Station, USA). We analyzed the delay data using non-parametric methods, because the times reported were not normally distributed, and because some values were extreme outliers, possibly because of errors in data collection or in women's interpretation of the key questions.

\section{Results}

All 19 eligible hospitals (8 in Recife, 7 in Salvador and 4 in São Luís) participated. A total of 3064 women were eligible, of whom $2.7 \%$ refused to participate and $5.8 \%$ were discharged or died (2 women) before they could be interviewed, leaving 2,804 women interviewed.

Fifty-eight percent of women were in Salvador, 27.1\% in São Luís, and 13.9\% in Recife. Most women (91.7\%) were under 30 years-of-age, with a mean age of 27.6 years $(\mathrm{SD}=6.3)$ and were mostly $(88.6 \%)$ married, cohabiting or in a stable relationship. The majority $(89.1 \%)$ declared themselves as non-white, but $0.4 \%$ did not classify themselves. Nearly two-thirds $(64.3 \%)$ had eight years of education or more. A third (35.5\%) was not working, but only 7\% had never worked.

\section{Box 1}

Criteria used to assess the clinical condition of abortion admissions.

\begin{tabular}{|l|l|}
\hline Very serious condition & $\begin{array}{l}\text { Any of the following: low level of consciousness (disoriented, lethargic or unconscious), severe hypotension (systolic < } \\
90 \mathrm{mmH} / \text { diastolic }<70 \mathrm{mmHg} \text { ) or a heart rate } \geq 140 \text { beats/minutes, septicaemia, septic shock, multiple organ failure, } \\
\text { generalised peritonitis or intrapelvic collection, or any sign of organ failure (disseminated intravascular coagulation, } \\
\text { hypovolemic shock, renal failure, respiratory distress syndrome or liver failure), or by management-based criteria, } \\
\text { such as, requirement for respiratory assistance, admission to intensive care, or having a hysterectomy or blood } \\
\text { transfusion. }\end{array}$ \\
\hline Serious condition & $\begin{array}{l}\text { Oriented, orthostatic hypotension, requiring replacement of blood or fluids, or heart rate between } 100-139 \text { beats/ } \\
\text { min, signs of infection (temperature }>38^{\circ} \mathrm{C} \text { or }<36^{\circ} \mathrm{C} \text { or intrapelvic collection), or pain at uterine mobilization with } \\
\text { localised peritonitis. }\end{array}$ \\
\hline Mild condition & $\begin{array}{l}\text { Having normal conversation, with signs of infection or offensive discharge, normal blood pressure or mild } \\
\text { hypotension (systolic }<140 \mathrm{mmHg} \text { and } \geq 90 \mathrm{mmHg} / \text { diastolic } \geq 70 \mathrm{mmHg} \text { ), and not requiring blood or fluids transfusion. }\end{array}$ \\
\hline Good condition & $\begin{array}{l}\text { Temperature between } 37.3-37.9^{\circ} \mathrm{C} \text { and normal blood pressure and no signs of infection, and not requiring fluid } \\
\text { reposition. }\end{array}$ \\
\hline
\end{tabular}




\section{Table 1}

Place women first sought care, type of places and hospitals visited.

\begin{tabular}{|c|c|}
\hline Place first visited & $\begin{array}{l}\text { Total } \\
\%(n)\end{array}$ \\
\hline Hospital & $76.6(2,145)$ \\
\hline Hospital (first and ultimate) & $47.2(1,012)$ \\
\hline Hospital (not ultimate) & $52.8(1,133)$ \\
\hline Health centre, poly clinic, primary health unit, private doctor, private clinic & $16.8(472)$ \\
\hline Non-health facility (pharmacy, traditional medicine at home, don't know, traditional birth attendant, others & $6.6(185)$ \\
\hline Total & $(2,802)$ \\
\hline \multicolumn{2}{|l|}{ Number of hospitals visited } \\
\hline 1 & $49.2(1,378)$ \\
\hline 2 & $25.2(706)$ \\
\hline $3-8$ & $25.6(718)$ \\
\hline Median (interquartile range) & $2(1-3)$ \\
\hline Total & $(2,802)$ \\
\hline \multicolumn{2}{|l|}{ Types of places visited before hospitalization } \\
\hline Hospitals only & $66.6(1,867)$ \\
\hline Hospital/s and other health facility/ies & $24.4(685)$ \\
\hline Hospital/s and non-health facility based provider/s & $6.7(187)$ \\
\hline Hospital/s, other health facility/ies and non-health facility based provider/s & $2.1(58)$ \\
\hline Other health facility/ies and non-health facility based provider/s & $0.2(5)$ \\
\hline Total & $(2,802)$ \\
\hline
\end{tabular}


Figure 1

Place women first sought care and places visited before arrive at the ultimate hospital.

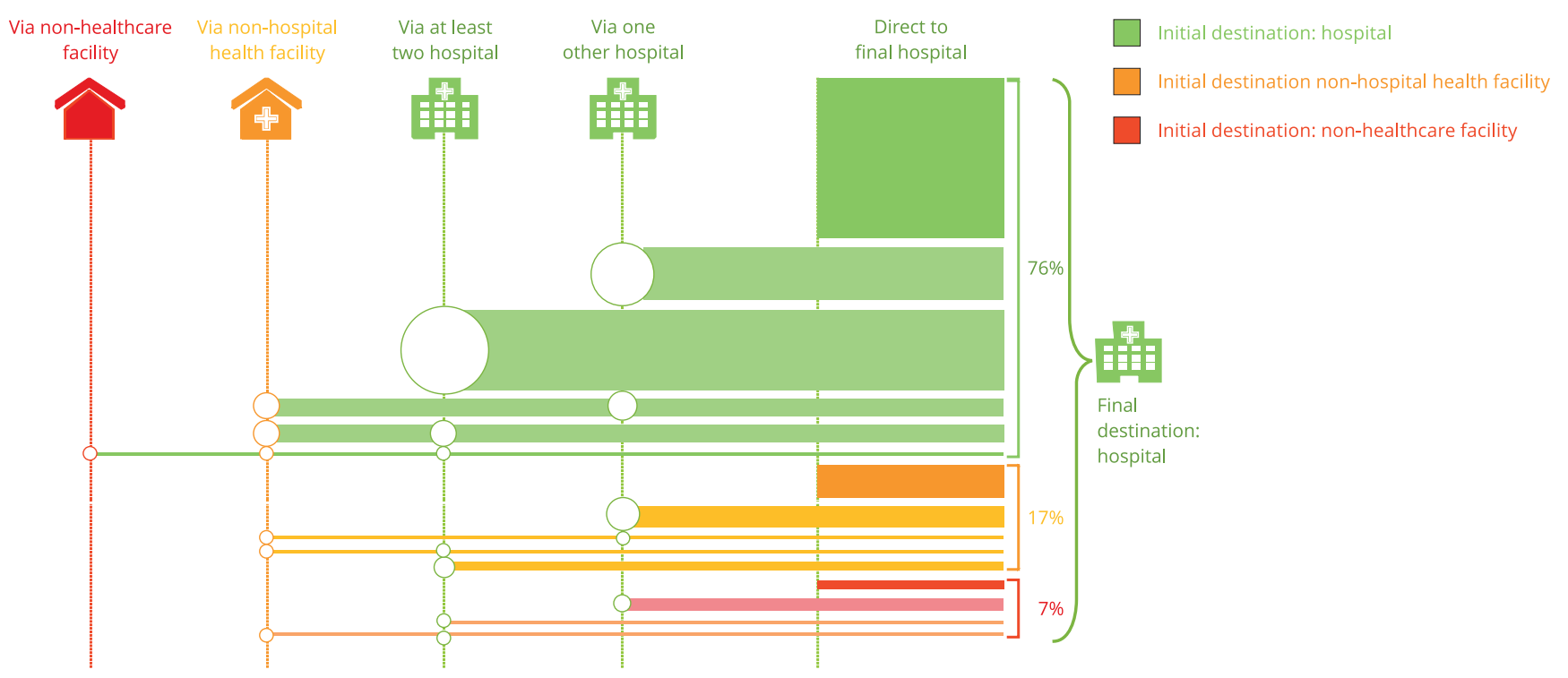

Table 2

Clinical condition on arrival at the ultimate hospital, overall and by numbers of hospitals visited.

\begin{tabular}{lcccc}
\hline Clinical condition & & Number of hospitals visited & & Total \\
& $\mathbf{1}$ & $\mathbf{2}$ & $\mathbf{3 +}(\mathbf{n})$ \\
& $\%(\mathbf{n})$ & $\mathbf{\%}(\mathbf{n})$ & $4.2(29)$ & $4.8(128)$ \\
Serious or very serious * & $5.6(75)$ & $3.6(24)$ & $3.6(25)$ & $3.7(99)$ \\
Mild & $4.4(59)$ & $2.3(15)$ & $92.1(631)$ & $91.6(2,467)$ \\
Good & $90.0(1,211)$ & $94.1(625)$ & $(685)$ & $(2,694)$ \\
Total & $(1,345)$ & $(664)$ & &
\end{tabular}

Pearson chi-square < 0.050;

* 18 women were classified as very serious.

bers of visited hospitals, from 15 hours, to 48 hours and 72 hours, for those going to two, or three, or more hospitals, respectively. Table 3 also shows times stratified by clinical condition on arrival at the ultimate hospital.

About 31\% of women reported having to overcome difficulties in searching for care. Reasons included shame and/or fear of being mistreated or humiliated by the health services, not having anyone to go with or to care for her children, lack of funds to pay for transport (or lack of means of transport) and fear of missing work. Only a few women mentioned underestimating the need of care or difficulty in knowing where to seek care. The percentage who declared they had experienced some difficulty in reaching the ultimate hospital was even lower (10\%), although reasons given for difficulties were quite similar. Around $27 \%$ of women experienced delays in being admitted to a hospital even after they arrived there. Reasons included waiting a long time for medical attention, having pregnant women prioritized over abortion cases, and having to wait for a hospital bed to become available (Table 4). 
Table 3

Time from symptoms to first care seeking decision (1st delay) and from symptoms to ultimate care seeking destination (1st and 2nd delay). Median (interquartile range) in hours.

$\begin{array}{lcc}\text { Number of hospitals from which women } & \text { Median (25-75 percentile) hours from } & \text { Median (25-75 percentile) hours from } \\ \text { sought care and condition on admission to } & \text { symptoms to the care seeking decision: } & \text { symptoms to arriving to the ultimate } \\ \text { ultimate hospital } & \text { First delay } & \text { destination hospital: } \\ & & \text { First and second delay }\end{array}$

\begin{tabular}{|c|c|c|c|c|}
\hline \multicolumn{5}{|l|}{ Any condition * } \\
\hline 1 hospital & $9(2-48)$ & & $15(4-72)$ & \\
\hline 2 hospitals & $12(2-51)$ & $p=0.617$ & $48(12-120)$ & $p=0.000$ \\
\hline 3+ hospitals & $12(1.5-48)$ & & $72(24-168)$ & \\
\hline Total & $10(2-48)$ & & $36(7-120)$ & \\
\hline \multicolumn{5}{|l|}{ Good * } \\
\hline 1 hospital & $8(2-48)$ & & $13(3.7-72)$ & \\
\hline 2 or more hospitals & $12(1.5-48)$ & $p=0.386$ & $65.5(20-144)$ & $p=0.000$ \\
\hline Total & $9(2-48)$ & & $32(6.5-120)$ & \\
\hline \multicolumn{5}{|l|}{ Mild * } \\
\hline 1 hospital & $41(8.3-72)$ & & $48.7(13.5-74.2)$ & \\
\hline 2 or more hospitals & $24(2-72)$ & $p=0.346$ & $96(47-192)$ & $p=0.005$ \\
\hline Total & $26(4-72)$ & & $72(18.7-120)$ & \\
\hline \multicolumn{5}{|l|}{ Serious or very serious * } \\
\hline 1 hospital & $24(5-72)$ & & $42(9.1-86.7)$ & \\
\hline $2+$ hospitals & $18(2.2-72)$ & $p=0.646$ & $96(24-210)$ & $p=0.004$ \\
\hline Total & $24(4-72)$ & & $53.5(9.5-120)$ & \\
\hline
\end{tabular}

\section{Discussion}

We investigated delays in care-seeking for abortion complications in Northeastern Brazil, contributing to a sparse literature in Brazil, and globally. The picture gained is mixed, indicating scope for improvement.

We sampled all women hospitalized for abortion-complications in the public sector and had an excellent response rate (91.5\%). Our limitations relate to the exclusion of minors 18 who face great barriers to access 19 , and of abortions managed entirely within the private sector. In addition, despite the apparent homogeneity of the study population, another limitation of this study is that it did not analyze the influence of social position and especially race/ethnicity in determining institutional barriers to access to services.

Our measurement of the time at various stages was also problematic, with heaped response-times, and questions misinterpreted by some women. For example, we could not differentiate the length of time spent between arrival at the first hospital, between subsequent hospitals and to the hospital in which women finally received uterine evacuation. In hindsight, care-seeking patterns should have been measured with a grid, and not structured questionnaires with skip patterns.

Women hospitalized for abortion complications took nearly half-a-day (10 hours) from first symptoms to decide to seek care. Comparable research in other settings is scarce, but this is shorter than in Kenya 20 where 54\% waited over a week, or Mexico where a qualitative study found most women waited two+ days 21 . Women recognize the need for care (99.6\%), but nearly a third experienced difficulties initiating care-seeking, including in finding money, transport, childcare or a companion, or getting time-off from work (total 17\%), and delays for fear, shame/embarrassment or stigma (11\%). Weak social support networks and precarious living conditions were clear issues for some women, though comparative data are few. Our setting, three state-capital cities, meant transport was a minor barrier, unlike settings with poor public transport 22. Women's fear/stigma were important reasons 
Difficulties experienced by women at various stages of care seeking *.

$\%$ (n)

$\begin{array}{lc}\text { Difficulties experienced by women in seeking care } & \\ \text { Had no difficulties } & 68.9(1,932) \\ \text { Had difficulties } & 31.1(871) \\ \text { Ashamed, or feared being mistreated or humiliated } & 12.8(360) \\ \text { Had no one to go with } & 5.7(161) \\ \text { Had no one with whom to leave her children } & 5.0(141) \\ \text { Had no money to pay for transport } & 6.7(137) \\ \text { Could not miss work } & 3.6(102) \\ \text { Did not know where to seek care } & 3.2(89) \\ \text { Faced difficulties in finding transport } & 3.3(94) \\ \text { Thought things would get better on their own } & 0.4(11) \\ \text { Other } & 2.3(64) \\ \text { Total } & (2,803) \\ \text { Difficulties experienced by women in getting admitted to hospital } & \\ \text { Had no difficulties } & 73.3(2,050) \\ \text { Experienced difficulties } & 26.7(746) \\ \text { Waited too long to be attended } & 15.4(430) \\ \text { Waited to have a bed } & 7.4(206) \\ \text { Pregnant women were prioritized instead } & 8.9(248) \\ \text { Others } & 3.4(96) \\ \text { Total } & (2,796)\end{array}$

* Percentages and totals are based on respondents; more than one answer was accepted.

for delay in Mexico 21, and dehumanized care, disrespect, abuse and judgmental behavior by health professionals were documented in Brazil 9, and elsewhere 8,23; even women with spontaneous abortions face discriminatory attitudes when health professionals assumed they were induced.

Women's life situations only partly led to delays; service-related factors and their interactions with the legal context are also important. We found that women are unclear about the referral system and are sometimes uncertain where to go. Nearly all women went straight to a health facility, but only a third went directly to the public sector hospital, where they were ultimately treated. The rest had various care-seeking combinations involving lower health system levels that were incapable of treating complications or treatment outside the health system. Some went to facilities capable of managing complications at some moments, but not others. Ultrasound is central to managing abortion in Brazil ${ }^{9}$, shortages of ultrasound professionals in the public health network at times limit care-capacity 24 . In such facilities, women may be asked to return later or be directed elsewhere. Occasionally, women went to high-risk reference hospitals, but were referred downward to less busy facilities. Such prolonged and complex seeking-care processes have been reported for stigmatized diseases such as HIV or tuberculosis 25,26 and are potentially aggravated by the illegality and stigma surrounding abortion.

Half the women spent $36+$ hours before reaching the ultimate hospital, and delay increased sharply with the number of hospital visited, from a median of 15 hours if only one hospital was visited, to 48 hours if two were visited, to 72 hours if $3+$ were visited. Each transfer, thus, added around 1.5 days per additional hospital, and may have led to more severe post-abortion complications 27,28. In Kenya 28, women who delayed 6+ hours arriving at a health facility had at least twice the odds of a moderate/ severe complication compared to those who sought care earlier (delay of 7-48 hours: OR = 2.12; of 3-7 days: $\mathrm{OR}=2.01$; and $7+$ days: $\mathrm{OR}=2.35$ ).

We found $92 \%$ of women arrived at the ultimate hospital in good condition, differing markedly from results in Kenya 20,29, Cambodia 30 and South Africa 31, which reported high-severity complications in $10 \%-42 \%$ of women, moderate-severity in $16 \%-40 \%$, and low-severity in $26 \%-72 \%$. This 
heterogeneity reflects differences in local context, and methods such as case severity definitions, age groups studied and whether spontaneous abortions were included. However, perhaps the main difference is that the public health system is free for all Brazilians, and most abortions in Brazil are induced with misoprostol, which can be effective and safe even when used illegally 9,12,14, resulting in shorter delays 32 .

We found women who arrived at the ultimate hospital in more compromised clinical conditions were slightly more likely to have delayed care-seeking from first symptoms. We cannot be certain when the signs of more severe complications started to emerge, but we had anticipated that women with more severe complications would have sought care earlier. The 3-hour difference seen may have been due to measurement error, or these women may have been either less likely to act or were less able to act swiftly. However, women with complications were little more likely to have been admitted to the first hospital they visited (59\% vs. $40 \%$ ), but those with complex pathways and long delays were more likely to have been admitted with complications. We also recognize that under Brazil's restrictive law, some women who unsuccessfully self-administered misoprostol and started bleeding may have had to seek care several times before providers were prepared to hospitalize them for "inevitable abortion" 9. In Kenya 20, the longer women waited to seek care, the more severe their complications on admission. We also found the longer a woman delayed before seeking care, the more severe was her clinical condition when presenting to the ultimate hospital. In contrast, those women with severe complications on arrival spent less time than the others in being admitted to a hospital, and a slightly lower percentage of them had visited a multiple hospital before being admitted.

Over a quarter of women reported difficulties in being admitted, suggesting a lack of beds and overburdened health facilities may be an important barrier, despite almost universal access to childbirth care 33 . A multi-centered national study 27 found that the risk of maternal death/near-miss was higher among women presenting with post-abortion complications, compared to other pregnancy complications. Pregnant women were attended more quickly than women with abortion complications, a finding also reported in Ghana 8, and Gabon 4. Obstetrician-gynecologists in Salvador 34, expressed their views that maternity-hospital beds should be reserved for pregnant women, although they also affirmed they would never refuse to attend women with post-abortion complications. Many thought women should not have the right to choose induced-abortion based on their needs.

\section{Conclusion}

Women in our study faced difficulties obtaining post-abortion care, and the time taken to access an appropriate facility had consequences for the severity of complications. The stigma surrounding abortion delayed women's care-seeking and gave them less priority in health facilities. Women also faced difficulties stemming from their less favorable life conditions and had unmet need for emergency obstetric care. To reach the Sustainable Development Goals, Brazil's challenge is to consolidate maternal/child health gains, to improve women's access and quality of care, and further reduce inequities by tackling marginalized health issues and marginalized women.

Further research on delays is recommended in settings with restrictive laws or access to abortion to clarify the impact of abortion stigma on women's decision-making process and providers' treatment behavior. New analyzes will be carried out to distinguish the inequities between women, which is already being done considering women's race/skin color. Recommendations include continuous surveillance on death and severe abortion complications, and changes in the process of training health professionals to recognize abortion not only as a public health problem, but as issue to the field of women's sexual and reproductive health. Furthermore, review of the Brazilian restrictive Law would contribute for reducing delays and allowing timely access to abortion-related complications. Legalization of abortion in other settings has reduced abortion-related complications and probably the time taken by women to seek care. 


\section{Contributors}

T. V. B. Araújo participated in designed and conducted the fieldwork; designed and conducted the analysis; prepared the first draft, participated in interpreting the results, drafting, and commenting on the paper. E. M. L. Aquino, G. M. S. Menezes, S. V. Alves, and L. Coimbra contributed in designed and conducted the fieldwork, and participated in interpreting the results, drafting, and commenting on the paper. M. T. S. S. B. Alves participated in designed and conducted the fieldwork and participated in interpreting the results, drafting, and commenting on the paper. M. C. C. Almeida participated in interpreting the results, drafting, and commenting on the paper. O. M. R. Campbell participated in designed the analysis, and in interpreting the results, drafting, and commenting on the paper.

\section{Acknowledgments}

We thank the Brazilian Ministry of Science and Technology, Brazilian National Research Council (CNPq) and Brazilian Ministry of Health for their support, the women who participated in these surveys, hospital staff and field workers (MCT/CNPq/ MS/SCTIE-DECIT n. 54/2008 - n. 402680/2008-1).

\section{References}

1. Ahman E, Shah IH. New estimates and trends regarding unsafe abortion mortality. Int J Gynaecol Obstet 2011; 115:121-6.

2. Singh S. Hospital admissions resulting from unsafe abortion: estimates from 13 developing countries. Lancet 2006; 368:1887-92.

3. Adler AJ, Filippi V, Thomas SL, Ronsmans C. Quantifying the global burden of morbidity due to unsafe abortion: magnitude in hospitalbased studies and methodological issues. Int J Gynaecol Obstet 2012; 118 Suppl 2:S65-77.

4. Mayi-Tsonga S, Oksana L, Ndombi I, Diallo T, de Sousa MH, Faúndes A. Delay in the provision of adequate care to women who died from abortion-related complications in the principal maternity hospital of Gabon. Reprod Health Matters 2009; 17:65-70.

5. Barnes-Josiah D, Myntti C, Augustin A. The "three delays" as a framework for examining maternal mortality in Haiti. Soc Sci Med 1998; 46:981-93.

6. Thaddeus S, Maine D. Too far to walk: maternal mortality in context. Soc Sci Med 1994; 38:1091-110.

7. Faundes A, Duarte GA, Osis MJ, Conscientious objection or fear of social stigma and unawareness of ethical obligations. Int J Gynaecol Obstet 2013; 123 Suppl 3:S57-9.

8. Tagoe-Darko E. "Fear, shame and embarrassment": the stigma factor in post abortion care at komfo anokye teaching hospital, Kumasi, Ghana. Asian Soc Sci 2013; 9:134-41.

9. Diniz D, Medeiros M, Itinerários e métodos do aborto ilegal em cinco capitais brasileiras. Ciênc Saúde Coletiva 2012; 17:1671-81.

10. Monteiro MFG, Adesse L, Drezett J. Atualização das estimativas da magnitude do aborto induzido, taxas por mil mulheres e razões por 100 nascimentos vivos do aborto induzido por faixa etária e grandes regiões. Brasil, 1995 a 2013. Reprod Clim 2015; 30:11-8.

11. Diniz D, Medeiros M, Madeiro A. National Abortion Survey 2016. Ciênc Saúde Coletiva 2017; 22:653-60.

12. Singh S, Monteiro MFG, Levin J. Trends in hospitalization for abortion-related complications in Brazil, 1992-2009: why the decline in numbers and severity? Int J Gynecol Obstet 2012; 118 Suppl 2:S99-106.

13. Faundes A, Santos LC, Carvalho M, Gras C. Post-abortion complications after interruption of pregnancy with misoprostol. Adv Contracept 1996; 12:1-9.

14. World Health Organization. Guidelines approved by the Guidelines Review Committee, in safe abortion: technical and policy guidance for health-systems. Geneva: World Health Organization; 2012.

15. Victora CG, Aquino EM, do Carmo Leal M, Monteiro CA, Barros FC, Szwarcwald CL. Maternal and child health in Brazil: progress and challenges. Lancet 2011; 377:1863-76. 
16. Departamento de Ações Programáticas Estratégicas, Secretaria de Atenção à Saúde, Ministério da Saúde. Manual dos comitês de mortalidade materna. Brasília: Ministério da Saúde; 2009. (Série A. Normas e Manuais Técnicos).

17. Secretaria de Atenção à Saúde, Ministério da Saúde. Atenção humanizada ao abortamento: norma técnica. 2a Ed. Brasília: Ministério da Saúde; 2011. (Série A. Normas e Manuais Técnicos) (Série Direitos Sexuais e Direitos Reprodutivos, Caderno 4).

18. Departamento de Análise de Situação em Saúde, Secretaria de Vigilância em Saúde, Ministério da Saúde. Saúde Brasil 2013: uma análise da situação de saúde e das doenças transmissíveis relacionadas à pobreza. Brasília: Ministério da Saúde; 2014.

19. Olukoya AA, Kaya A, Ferguson BJ, AbouZahr C. Unsafe abortion in adolescents. Int J Gynaecol Obstet 2001; 75:137-47.

20. Izugbara C, Kimani E, Mutua M, Mohamed S, Ziraba A, Egesa C. Incidence and complications of unsafe abortion in Kenya: key findings of a national study. http://www.guttmacher. org/sites/default/files/report_pdf/abortionin-kenya.pdf (accessed on 08/Mai/2018);

21. van Dijk MG, Ahued Ortega A, Contreras X, García SG. Stories behind the statistics: a review of abortion-related deaths from 2005 to 2007 in Mexico City. Int J Gynaecol Obstet 2012; 118 Suppl 2:S87-91.

22. Hirose A, Borchert M, Niksear H, Alkozai AS, Cox J, Gardiner J, et al. Difficulties leaving home: a cross-sectional study of delays in seeking emergency obstetric care in Herat, Afghanistan. Soc Sci Med 2011, 73:1003-13.

23. Steele C, Chiarotti S. With everything exposed: cruelty in post-abortion care in Rosario, Argentina. Reprod Health Matters 2004; 12 (24 Suppl):39-46.

24. Alves MTSSB, Barreto-de-Araújo TV, Alves SV, Marinho LFB, Schiavo E, Menezes G. et al. Atenção ao aborto no Sistema Único de Saúde no Nordeste Brasileiro: a estrutura dos serviços. Rev Bras Saúde Matern Infant 2014; 14:229-39.

25. Wynne A, Richter S, Jhangri GS, Alibhai A, Rubaale T, Kipp W. Tuberculosis and human immunodeficiency virus: exploring stigma in a community in western Uganda. AIDS Care 2014; 26:940-6.
26. Kapoor SK, Raman AV, Sachdeva KS, Satyanarayana $S$. How did the TB patients reach DOTS services in Delhi? A study of patient treatment seeking behavior. PLoS One 2012; 7:e42458.

27. Santana DS, Cecatti JG, Parpinelli MA, Haddad SM, Costa ML, Sousa MH, et al. Severe maternal morbidity due to abortion prospectively identified in a surveillance network in Brazil. Int J Gynaecol Obstet 2012; 119:44-8.

28. Ziraba AK, Izugbara C, Levandowski BA, Gebreselassie H, Mutua M, Mohamed SF, et al, Unsafe abortion in Kenya: a cross-sectional study of abortion complication severity and associated factors. BMC Pregnancy Childbirth $2015 ; 15: 34$

29. Gebreselassie H, Gallo MF, Monyo A, Johnson $\mathrm{BR}$. The magnitude of abortion complications in Kenya. BJOG 2005; 112:1229-35.

30. Fetters T, Vonthanak S, Picardo C, Rathavy T. Abortion-related complications in Cambodia. BJOG 2008; 115:957-68.

31. Jewkes R, Brown H, Dickson-Tetteh K, Levin J, Rees H. Prevalence of morbidity associated with abortion before and after legalisation in South Africa. BMJ 2005; 324:1252-3.

32. Paim J, Travassos CMR, Almeida CM, Bahia L, Macinko J. The Brazilian health-system: history, advances, and challenges. Lancet 2011; 377:1778-97.

33. Lago TDG, Lima LP. Assistência à gestação, ao parto e ao puerpério: diferenciais regionais e desigualdades socioeconômicas. In: Ministério da Saúde, organizador. Pesquisa Nacional de Demografia e Saúde da Criança e da Mulher PNDS 2006: dimensões do processo reprodutivo e da saúde da criança. Brasília: Ministério da Saúde; 2009. p. 151-70. (Série G. Estatística e Informação em Saúde).

34. De Zordo S, Mishtal J. Physicians and abortion: provision, political participation and conflicts on the ground: the cases of Brazil and Poland. Womens Health Issues 2011; 21(3 Suppl):S32-6. 


\section{Resumo}

Cerca de 18 milhões de abortos são realizados por ano em condições inseguras nos países de renda baixa e média, associados a numerosas consequências negativas para a saúde das mulheres. O tempo despendido pelas mulheres com complicações até chegar aos serviços onde possam receber os cuidados adequados no período pós-aborto podem influenciar o risco de morte e o grau das complicações posteriores. Foram entrevistadas todas as mulheres com 18 anos ou mais internadas devido a complicações do aborto em hospitais públicos em capitais estaduais do Nordeste brasileiro entre agosto e dezembro de 2010, e os prontuários foram analisados $(N=2.804)$. Quase todas as mulheres (94\%) se dirigiram diretamente a um serviço de saúde, principalmente hospitais $(76,6 \%)$, enquanto as outras seguiram diversos itinerários em busca de atendimento. Uma em cada quatro mulheres percorreu três ou mais hospitais. As mulheres esperavam uma média de dez horas antes de decidir buscar atendimento. 29\% relatavam dificuldades no início da busca, inclusive desafios na organização dos cuidados dos filhos, com acompanhantes ou transporte (17\%) e medo/estigma (11\%). Uma pequena minoria $(0,4 \%)$ não se deu conta inicialmente da necessidade de cuidados médicos. $O$ tempo mediano para chegar até o serviço de saúde finalmente utilizado foi 36 horas. Mais de uma em cada quatro mulheres relatava dificuldades em conseguir internação hospitalar, inclusive tempo de espera prolongado (15\%), atendimento apenas depois que todas as mulheres grávidas estivessem sido atendidas $(8,9 \%)$ e espera por um leito $(7,4 \%)$. Quase todas as mulheres (90\%) chegavam em boas condições, mas aquelas sujeitas a esperas mais prolongadas mostraram maior probabilidade de complicações (tanto leves quanto graves). No Brasil, onde o acesso ao aborto induzido é restrito, as mulheres enfrentam muitas dificuldades para receber cuidados pós-aborto, o que contribui aos atrasos $e$ impacta a gravidade das complicações pós-aborto.

Aborto; Acesso aos Serviços de Saúde; Cuidados Médicos

\section{Resumen}

Cerca de 18 millones de abortos inseguros se producen en países de renta media o baja y están asociados con numerosas consecuencias adversas para la salud de la mujer. El tiempo que tardan las mujeres con complicaciones en llegar a los servicios médicos, donde puedan recibir cuidados apropiados tras un aborto, puede tener influencia en el riesgo de muerte y existencia de futuras complicaciones de salud. Todas las mujeres con $18+$ años, admitidas por complicaciones durante un aborto en hospitales del sector público de tres capitales del Nordeste brasileño, entre agosto $y$ diciembre de 2010, fueron entrevistadas; $y$ sus historiales médicos resumidos $(N=2.804)$. Casi todas las mujeres (94\%) fueron directamente a una institución sanitaria, en su mayoría un hospital (76,6\%); el resto buscaron diferentes vías de cuidados, con una cuarta parte visitando 3+ hospitales. Las mujeres esperaron 10 horas de media antes de decidir buscar cuidados. Un 29\% informó de dificultades al empezar a buscar cuidados, incluyendo el hacer frente a los desafíos para organizar el cuidado infantil, un acompañante o transporte (17\%) $y$ miedo/estigma (11\%); otras en un principio no reconocieron la necesidad de cuidados (0,4\%). La media de tiempo que les llevaba llegar al servicio de salud definitivo era 36 horas. Más de un cuarto de las mujeres informaron vivir dificultades estando admitidas en un hospital, incluyendo largas esperas (15\%), sólo siendo atendidas tras las mujeres embarazadas $(8,9 \%)$ y esperando una cama $(7,4 \%)$. Casi todas las mujeres (90\%) llegaron en buenas condiciones, pero aquellas con retrasos más largos eran las que estaban más expuestas a tener complicaciones (leves o graves). En Brasil, donde el acceso al aborto inducido está limitado, las mujeres se enfrentan a numerosas dificultades para recibir cuidado tras un aborto, lo que contribuye a retrasos e influye en la gravedad de las complicaciones post aborto.

Aborto; Accesibilidad a los Servicios de Salud; Atención Médica
Submitted on $28 / \mathrm{Sep} / 2016$

Final version resubmitted on 05/Aug/2017

Approved on 04/Dec/2017 